\title{
Penegakan Hukum Pemberantasan Tindak Pidana Korupsi Pasca Putusan Mahkamah Konstitusi Nomor 25/PUU-XIV/2016
}

\author{
Rio Rinaldi Silalahi \\ Program Pascasarjana Fakultas Hukum Universitas Islam Indonesia \\ Jln. Cik Di Tiro No. 1, Yogyakarta, 55223 \\ Silalahi.plr@gmail.com
}

\begin{abstract}
This study aims to determine the perspectives of Advocates and Corruption Eradication Commission (KPK) on the decision of the Constitutional Court (MK) No. 25/PUU-XIV/2016 concerning the removal of the word "can"; and how the law enforcement practices were carried out by Advocates and KPK after the Constitutional Court's decision. This research is normative with an empirical dimension and a juridical approach. The method used in analyzing the data is qualitative. The results show that, the perspective of the post-verdict advocate MK No. 25/PUU-XIV/2016 namely the change in formal offense to material offense is considered to provide fairer legal certainty. While the KPK's perspective on the decision was considered counterproductive in an effort to prevent state financial losses due to corruption. The implication is that the KPK is increasingly difficult to ensnare criminal acts of corruption from the natural resource or environmental sector that are potentially detrimental to state finances. Law enforcement practices carried out by lawyers after the Constitutional Court's decision have not been fully optimal. While the law enforcement practices carried out by the KPK after the Constitutional Court's ruling are as usual because before the Constitutional Court's ruling, the KPK always bases state financial losses with certainty, even if they create potential state losses, also attaching certainty (Both).
\end{abstract}

Keywords: Advocates; KPK; corruption; law enforcement; constitutional court's decision

\begin{abstract}
Abstrak
Penelitian ini bertujuan untuk mengetahui perspektif Advokat dan KPK terhadap putusan Mahkamah Konstitusi (MK) No. 25/PUU-XIV/2016 tentang penghapusan kata "dapat"; dan bagaimana praktek penegakan hukum yang dilakukan Advokat dan KPK pasca putusan MK tersebut. Penelitian ini bersifat normatif yang berdimensi empiris dengan pendekatan yuridis. Metode yang digunakan dalam menganalisa data bersifat kualitatif. Hasilnya menyimpulkan bahwa, perspektif advokat pasca-putusan MK No. 25/PUU-XIV/2016 yaitu perubahan delik formiil menjadi delik materiil dianggap lebih memberikan kepastian hukum yang adil. Sementara perspektif KPK terhadap putusan tersebut dinilai kontraproduktif dalam upaya mencegah kerugian keuangan negara akibat korupsi. Implikasinya, KPK semakin sulit untuk menjerat tindak pidana korupsi yang dari sektor sumber daya alam atau lingkungan yang sifatnya berpotensi merugikan keuangan negara. Praktik penegakan hukum yang dilakukan oleh advokat pasca putusan MK belum sepenuhnya optimal. Sementara praktik penegakan hukum yang dilakukan oleh KPK pasca putusan MK adalah seperti biasanya karena sebelum adanya putusan MK, KPK selalu mendasarkan kerugian keuangan negara secara pasti, jika pun mereka membuat kerugian negara secara potensi, juga melampirkan yang pasti (Keduanya).
\end{abstract}

Kata-kata Kunci: Advokat; KPK; korupsi; penegakan hukum; putusan Mahkamah Konstitusi 


\section{Pendahuluan}

Pembukaan Undang-Undang Dasar 1945, alinea ke-IV menyebutkan bahwa tujuan nasional negara Indonesia adalah, "Melindungi segenap Bangsa Indonesia dan seluruh tumpah darah Indonesia, memajukan kesejahteraan umum, mencerdaskan kehidupan bangsa, dan ikut serta melaksanakan ketertiban dunia berdasarkan kemerdekaan, perdamaian abadi dan keadilan sosial."1

Tujuan negara Indonesia tersebut akan sulit tercapai jika korupsi masih merajalela dan menjadi suatu budaya. Dilihat dari sudut pandang terminologi, istilah korupsi berasal dari kata "corruptio" dalam bahasa latin, yang berarti kerusakan atau kebobrokan, dan dipakai pula untuk menunjuk suatu keadaan atau perbuatan yang busuk. ${ }^{2}$ Korupsi diartikan sebagai tindakan pejabat publik, baik politisi maupun pegawai negeri, serta pihak lain yang secara tidak wajar dan tidak legal menyalahkan kepercayaan yang dikuasakan kepada mereka untuk mendapatkan keuntungan sepihak.

Fenomena tindak pidana korupsi selalu menjadi perhatian setiap negara di penjuru dunia, termasuk Indonesia. Korupsi merupakan permasalahan serius dan tergolong sebagai extraordinary crime yang dapat memberikan efek negatif dalam seluruh bidang kehidupan, dan juga dapat membahayakan stabilitas dan keamanan masyarakat, membahayakan pembangunan sosial ekonomi, dan juga politik, serta dapat merusak nilai-nilai demokrasi dan moralitas karena korupsi lambat laun akan menjadi budaya. Oleh karena itu, korupsi adalah suatu ancaman terhadap cita-cita menuju masyarakat adil dan makmur, sehingga dalam penanganan pemberantasannya diperlukan penanganan yang ekstra pula. Alatas mengatakan, korupsi jika terus dibiarkan pada akhirnya akan membunuh masyarakat (destroyed the fabric of society). ${ }^{3}$

Berdasarkan penelitian yang dilakukan Indonesia Corruption Watch (ICW), Pasal 2 ayat (1) dan Pasal 3 UU Nomor 31 Tahun 1999 - yang kemudian diubah menjadi UU Nomor 20 Tahun 2001 - tentang Pemberantasan Tindak Pidana

\footnotetext{
${ }^{1}$ KIF Aminanto, Politik. Hukum Pidana, Jember Kata Media, Jember, 2017, hlm. 2.

2 Elwi Danil, Korupsi: Konsep, Tindak Pidana dan Pemberantasannya, Rajawali Press, Jakarta, 2012, hlm. 3.

${ }^{3}$ Satjipto Rahardjo, 'Penegakan Hukum Progresif”, Kompas, Jakarta, 2010, hlm. 90.
} 
Korupsi merupakan favorit aparat penegak hukum dalam menjerat pelaku korupsi. Dari 735 kasus korupsi yang diperiksa dan diputus ditingkat kasasi Mahkamah Agung (MA) pada 2013, sebanyak 503 perkara (68,43\%) menggunakan Pasal 3 UU Pemberantasan Tipikor. Sedangkan 147 perkara (20\%) pelaku dijerat dengan Pasal 2 UU Pemberantasan Tipikor. Keadaan ini menunjukkan bahwa Pasal 2 ayat (1) dan Pasal 3 adalah primadona dalam UU Tipikor, sehingga tidak mengherankan apabila sering menjadi sasaran uji materi (judicial revieww). ${ }^{4}$

Penghapusan kata "dapat" pada Putusan Mahkamah Konstitusi (MK) Nomor 25/PUU-XIV/2016 ini bermula dari permohonan yang diajukan oleh 7 orang Pemohon dengan latar belakang Aparatur Sipil Negara (ASN) dan pensiunan ASN dari berbagai daerah yang berbeda. Tiga orang dari tujuh Pemohon mendudukkan dirinya sebagai korban akibat keberlakuan Pasal 2 ayat (1) dan Pasal 3 UU Tipikor karena telah didakwa berdasarkan ketentuan a quo. Sedangkan Pemohon lainnya mendalilkan bahwa ketentuan a quo berpotensi merugikan hak konstitusionalnya dalam kedudukannya sebagai Aparatur Sipil Negara (ASN). Sebagai ASN, para Pemohon kerap mengeluarkan keputusan dalam hal pelaksanaan kebijakankebijakan, berupa pelaksanaan proyek-proyek pembangunan di daerahnya masing-masing. Kebijakan tersebut berpotensi dipidana dengan keberlakuan ketentuan tersebut.

Dalam redaksinya pasal tersebut, terdapat penambahan frasa "dapat". Hal ini dimaknai bahwa unsur kerugian negara atau perekonomian negara tidak perlu ada. Dengan demikian, unsur kerugian negara atau perekonomian negara bisa masih dalam tahap potensi (potential loss). Karena kerugian yang dimaksud dalam Pasal 2 ayat (1) dan 3 tidak harus terjadi, sehingga jenis deliknya adalah delik formil. Delik formil merupakan delik yang menitikberatkan pada perbuatan, tanpa mensyaratkan adanya akibat. Bahwa unsur kerugian dan perekonomian negara, baik dalam Pasal 2 ayat (1) dan 3 UU No. 31 Tahun 1999 tentang Pemberantasan Tindak Pidana Korupsi tidak harus berupa kerugian yang nyata (actual loss).

4 "Hasil Penelitian Penerapan Unsur Merugikan Keuangan Negara dalam Delik Tindak Pidana Korupsi" http://www.antikorupsi.org/sites/antikorupsi.org/files/doc/Kajian/policypaperkeuangannegara.pdf. Diakses tanggal 1 Agustus 2018. 
Keadaan ini mengalami perubahan ketika frasa "dapat merugikan keuangan negara atau perekonomian negara" di judicial review.

Penggunaan kata "dapat" tersebut oleh Pemohon dianggap berpotensi menimbulkan penyalahgunaan wewenang oleh aparat penegak hukum untuk memutus perkara, sehingga unsur obyektivitas sulit dibuktikan. Dengan adanya Putusan MK yang menghapuskan kata "dapat" dalam Pasal 2 ayat (1) dan Pasal 3 undang-undang tindak pidana korupsi, mengakibatkan delik korupsi yang selama ini merupakan delik formil berubah menjadi delik materiil yang mensyaratkan ada akibat yakni unsur kerugian keuangan negara harus dihitung secara nyata atau pasti. Terkait penerapan unsur merugikan keuangan negara telah bergeser dengan menitikberatkan adanya akibat (delik materiil), yang mana unsur merugikan keuangan negara tidak lagi dipahami sebagai perkiraan (potential loss), tetapi harus dipahami benar-benar sudah terjadi nyata (actual loss) dalam tindak pidana korupsi.

Lebih jauh, Pemohon merasa pencantuman kata "dapat" pada Pasal 2 ayat (1) dan Pasal 3 UU Tipikor sebelumnya pada praktiknya sering disalahgunakan untuk menjangkau banyak perbuatan yang diduga merugikan keuangan negara termasuk kebijakan atau keputusan diskresi yang bersifat mendesak dan belum ditemukan landasan hukumnya. Ketika hal tersebut terus terjadi, maka potensi kriminalisasi yang mengatasnamakan penyalahgunaan wewenang akan sering terjadi, dan dampaknya akan menimbulkan keresahan bagi warga negara yang juga sebagai pemegang wewenang atau kekuasaan tidak mendapatkan rasa aman dan keadilan.

MK dalam perjalanan prosesnya kemudian mengabulkan dalil pemohon untuk menghapuskan kata "dapat" melalui putusan MK No. 25/PUU-XIV/2016. Dalam salah satu pertimbangan dalam putusan tersebut, MK berpandangan bahwa penerapan unsur kerugian negara dengan menggunakan konsepsi actual loss lebih memberikan kepastian hukum yang adil dan bersesuaian dengan upaya sinkronisasi dan harmonisasi antar instrumen hukum dan menganggap adanya kata "dapat" bertentangan dengan Undang-Undang Dasar 1945. Pasca keluarnya putusan MK tersebut, maka terjadi perubahan dalam unsur "dapat merugikan keuangan negara dan perekonomian negara". Sebelum keluar putusan MK, maka 
Pasal 2 ayat (1) dan 3 UU Tipikor termasuk delik formil, yang tidak mensyaratkan akibat berupa kerugian keuangan dan perekonomian negara. Namun setelah keluarnya putusan MK, Pasal 2 ayat (1) dan 3 UU Tipikor menjadi delik materiil, dengan mensyaratkan harus ada akibat berupa kerugian keuangan dan perekonomian negara. Dengan demikian, ada perubahan dari potential loss saja ke arah actual loss.

Keberhasilan para pemohon dalam memperjuangkan kepentingankepentingan yang dirasa merugikan atau berpotensi dirugikan dengan adanya kata "dapat" pada UU Tipikor sebelum putusan MK tersebut tidaklah terlepas dari peran jasa hukum atau advokat yang membela atau memperjuangkan kepentingan-kepentingan kliennya. Dalam Pasal 1 ayat (1) Undang-Undang Nomor 18 Tahun 2003 tentang Advokat menyebutkan bahwa advokat adalah orang yang berprofesi memberi jasa hukum, baik di dalam maupun di luar pengadilan yang memenuhi persyaratan. Peran advokat dalam proses hukum tidak dapat dipandang sebelah mata karena keberhasilan ataupun kegagalan proses hukum salah satunya ditentukan dari kinerja dan performa advokat dalam memperjuangkan kepentingan kliennya. Keahlian dan pemahaman yang baik dari internal advokat sendiri adalah suatu tuntutan di tengah dinamika masyarakat yang terus berkembang dan upaya pemberantasan tindak pidana korupsi yang semakin masif dilakukan oleh pemerintah. Berjalan atau tidaknya penegakan hukum di Indonesia salah satu dapat dilihat dari perspektif advokat dalam menerapkan hukum yang berlaku di Indonesia. Peran advokat dalam penegakan hukum sangatlah penting untuk mengimbangi penegakan hukum yang dilakukan dari sisi pemerintah, baik Polri, Kejaksaan, maupun Komisi Pemberantasan Korupsi (KPK) sebagai lembaga yang berwenang menangani korupsi di Indonesia.

Jika advokat adalah representatif dari para pihak ataupun masyarakat yang ingin memperjuangkan kepentingan-kepentingannya dalam upaya pemberantasan tindak pidana korupsi, maka dari sisi negara, salah satu lembaga yang berwenang dalam upaya pemberantasan tindak pidana korupsi dan terkena dampak atas adanya putusan MK No. 25/PUU-XIV/2016 tentang penghapusan kata "dapat" adalah KPK. KPK di Indonesia merupakan salah satu lembaga pemberantasan tindak pidana korupsi yang secara langsung berdampak terhadap 
penegakan hukum tindak pidana korupsi pasca putusan Mahkamah Konstitusi Nomor 25/PUU-XIV/2016 tentang penghapusan kata "dapat". Salah satu tolok ukur berjalan atau tidaknya penegakan hukum dapat dilihat dari kinerja KPK yang merupakan representatif dari pemerintah. Selain itu, banyak kasus korupsi yang ditangani oleh KPK, tuntutan terhadap terdakwa korupsi jauh lebih berat dibandingkan dengan tuntutan yang ditangani oleh Jaksa Penuntut Umum dari kejaksaan sehingga berpengaruh terhadap putusan dan besaran pengembalian kerugian keuangan negara. Hal ini menjadi menarik dalam praktik penegakan hukum tindak pidana korupsi di Indonesia, terlebih sejak adanya putusan MK terbaru tentang penghapusan kata "dapat" yang berdampak aparatur penegak hukum termasuk KPK harus dapat membuktikan adanya kerugian keuangan negara sebelum melakukan penyelidikan perkara korupsi.

\section{Rumusan Masalah}

Berdasarkan latar belakang di atas, maka permasalahan dalam penelitian ini dirumuskan sebagai berikut. Pertama, bagaimana perspektif Advokat dan KPK terhadap putusan Mahkamah Konstitusi Nomor 25/PUU-XIV/2016 tentang penghapusan kata "dapat"? Kedua, bagaimana praktik penegakan hukum yang dilakukan Advokat dan KPK pasca putusan Mahkamah Konstitusi Nomor 25/PUU-XIV/2016 tersebut?

\section{Tujuan Penelitian}

Dalam rencana penelitian ini, peneliti bertujuan untuk mendapatkan hasil yakni sebagai berikut. Pertama, mengetahui Perspektif Advokat dan KPK terhadap putusan Mahkamah Konstitusi Nomor 25/PUU-XIV/ 2016 tentang penghapusan kata "dapat". Kedua, mengetahui praktek penegakan hukum yang dilakukan Advokat dan KPK pasca putusan Mahkamah Konstitusi Nomor 25/PUU-XIV/2016 tersebut.

\section{Metode Penelitian}

Jenis penelitian ini berupa penelitian hukum normatif yang berdimensi empiris dan metode pendekatan yang digunakan adalah pendekatan yuridis 
normatif dan yuridis empiris. Sesuai dengan metode yang digunakan, maka pendekatan yang digunakan dalam menganalisa data berupa metode analisis kualitatif.

\section{Hasil Penelitian dan Pembahasan}

\section{Perspektif Advokat dan KPK terhadap Putusan MK Nomor 25/PUU-XIV/2016}

Putusan MK Nomor 25/PUU-XIV/2016 tentang penghapusan kata "dapat" tidak hanya berimplikasi pada perubahan delik tindak pidana yang semula adalah formil menjadi materiil namun juga berpengaruh pada tataran praktik pemberantasan tindak pidana baik yang dilakukan oleh advokat, jaksa, polisi serta aparat penegak hukum yang lain.

Tindak Pidana Korupsi adalah salah satu bagian dari hukum pidana khusus, di samping mempunyai spesifikasi tertentu yang berbeda dengan hukum pidana umum, yaitu dengan adanya penyimpangan hukum pidana formil atau hukum acara. ${ }^{5}$ Sementara Pasal 2 ayat (1) dan Pasal 3 UU Tipikor sendiri termasuk dalam kelompok delik yang dapat merugikan keuangan negara atau perekonomian Negara. 6 Pada pembahasan ini, penulis ingin mengetahui pandangan atau perspektif advokat kaitannya tentang penghapusan kata "dapat" sebelum dan setelah putusan MK Nomor 25/PUU-XIV / 2016.

Salah satu advokat yaitu Maqdir Ismail yang sering menangani kasus korupsi di Indonesia, termasuk kasus oknum yang terjerat Pasal 2 ayat (1) dan 3 UU Tipikor, menyampaikan bahwa adanya kata "dapat" pada Pasal 2 ayat (1) atau Pasal 3 UU Tipikor telah menimbulkan korban ketidakpastian hukum dan menimbulkan ketidakadilan. Hal ini dianggap tidak sesuai dengan tujuan hukum sendiri yaitu memberikan kepastian hukum dan menciptakan keteraturan dalam masyarakat serta melanggar Undang-Undang dasar 1945.

Hal yang sama juga disampaikan oleh Adi Mansar, beliau menganggap adanya frasa "dapat" pada Pasal 2 ayat (1) dan 3 terlalu bias. Tindak pidana korupsi haruslah benar-benar terukur dan harus dapat dibuktikan secara nyata serta jelas unsur merugikan keuangan negara. Delik tindak pidana korupsi yang sebelumnya

\footnotetext{
${ }^{5}$ Ermansjah Djaja, Tipologi Tindak Pidana Korupsi di Indonesia, Mandar Maju, Bandung, 2010, hlm. 32.

${ }^{6}$ Chaerudin, Syaiful Ahmad Dinar, Syarif Fadillah, Op. Cit., hlm. 4.
} 
merupakan delik formil yaitu berupa potensial loss seringkali disalahgunakan oleh Polri ataupun jaksa sehingga dijadikan dasar dalam melakukan proses penyelidikan maupun penyidikan tanpa disertai dengan pengamatan fakta-fakta yang jelas dan terukur. Dengan perubahan delik materiil pasca putusan MK tersebut dapat memberikan kepastian hukum bagi para pihak khususnya subyek hukum pada Pasal 2 ayat (1) dan Pasal 3 tersebut.7

Seorang advokat di Yogyakarta yang bernama Kardi, sependapat dengan Putusan MK tersebut. Menurut beliau,

“Pencantuman kata 'dapat' membuat delik kedua pasal tersebut menjadi delik formil. Padahal, praktiknya sering disalahgunakan untuk menjangkau banyak perbuatan yang diduga merugikan keuangan negara termasuk kebijakan atau keputusan diskresi atau pelaksanaan asas freies ermessen yang bersifat mendesak dan belum ditemukan landasan hukumnya. Ini bisa berakibat terjadi kriminalisasi dengan dugaan terjadinya penyalahgunaan wewenang. Dalam hal bisnis juga sering terjadi masalah ketika klien saya harus bermasalah dengan hukum khususnya korupsi, mendapatkan proyek dari pemerintah untuk memasang lampu jalan, akan tetapi praktiknya tanah yang di gali mempunyai keadaan yang berbeda beda, seperti beberapa titik yang ada bekas coran sehingga sulit dalam prosesnya. Sementara jika di pindahkan masyarakat tidak mau. Akhirnya klien saya di anggap merugikan keuangan negara karena waktu yang di janjikan tidak sesuai. Jika dilihat dari kasus tersebut harusnya klien saya tidak dapat di hukum karena tidak mengambil atau memotong uang yang merugikan keuangan negara, hanya saja pengerjaan yang sedikit membutuhkan waktu." ${ }^{\prime}$

Pemahaman tersebut selaras dengan beberapa prinsip dalam penegakan hukum pidana yang merupakan kerangka acuan berupa Model Law yang dibuat oleh Organization for Economic Co-Operation and Development (OECD) sebagai pedoman dalam rangka menghindari persoalan under and overcriminalizaation sehubungan dengan penegakan hukum pidana, yang antara lain meliputi prinsipprinsip: ${ }^{9}$

a. Precision principle, yakni ketentuan hukum pidana harus tepat dan teliti dalam mendeskripsikan suatu tindak pidana. Untuk itu perumusan hukum pidana yang bersifat samar dan umum harus dihindari;

\footnotetext{
${ }^{7}$ Wawancara dengan Adi Mansar, Advokat, 25 Agustus 2018.

8 Wawancara dengan Kardi, Advokat, 28 Agustus 2018

9 Teguh Prasetyo, Kriminalisasi Dalam Hukum Pidana, Cetakan Kesatu, Nusa Media, Bandung, 2010, hlm 40-
} 41. 
b. Clearness principle, yakni tindakan yang dikriminalisasikan harus dijabarkan secara jelas dalam ketentuan hukum pidana;

c. Principle of differentiation, yakni harus jelas perbedaan antara yang satu dengan yang lain. Maka dalam hukum pidana harus menghindari perumusan yang bersifat global atau terlalu luas, multipurpose atau all embracing;

Rumusan frasa "dapat" pada Pasal 2 ayat (1) dan 3 tidaklah mencerminkan prinsip-prinsip penegakan hukum karena bersifat samar, menimbulkan multitafsir karena bisa disalahgunakan oleh aparat penegak hukum untuk menjerat masyarakat dengan pasal tersebut.

Lebih lanjut, Maqdir Ismail menyampaikan adanya putusan Mahkamah Konstitusi Nomor 25/PUU-XIV/2016 tentang penghapusan kata "dapat" sangat dinilai positif karena diharapkan dapat memberikan keadilan kepada semua masyarakat khususnya terhadap oknum yang berpotensi terjerat dakwaan Pasal 2 ayat (1) dan Pasal 3 karena:

a. Bahwa keberadaan kata "dapat" dalam Pasal 2 ayat (1) dan Pasal 3 UU Tipikor, menciptakan ketidakpastian hukum, karena membuka peluang kemungkinan terbukti atau tidak terbukti "merugikan keuangan Negara atau perekonomian negara", menjadi alasan bagi penegak hukum termasuk hakim untuk menghukum seseorang yang didakwa melakukan perbuatan pidana korupsi;

b. Bahwa hilangnya kata dapat akan memberikan kepastian hukum yang adil (sebagaimana dimaksud dalam Pasal 28D ayat (1) UUD 1945) dengan menjamin keberlangsungan pemberantasan korupsi yang dilakukan menurut hukum dan dilakukan dengan berkeadilan;

c. Bahwa dalam praktik hukum dan kehidupan nyata kata "dapat" itu baru merupakan asumsi dan belum tentu terjadi, bahkan bisa saja tidak terjadi. Sedangkan perbuatan yang dapat dihukum itu adalah perbuatan riil, perbuatan yang sudah terjadi, paling kurang ada permulaan perbuatan, sebab perbuatan yang dapat dihukum adalah perbuatan pasti sudah terjadi;

d. Bahwa hilangnya kata "dapat" merugikan keuangan Negara atau perekonomian negara dalam kegiatan antara bisnis termasuk pada lembaga yang menggunakan fasilitas negara atau pemegang sahamnya negara atau mendapatkan izin khusus dari negara, sepanjang tidak diakui adanya penyelesaian administrasi atau melalui hukum perdata, maka hal ini dapat menimbulkan kriminalisasi atas suatu kegiatan bisnis termasuk karena adanya perjanjian;

e. Bahwa hilangnya kata "dapat", penyidik tidak dapat menetapkan seseorang menjadi tersangka korupsi, penuntut umum tidak dapat menuntut seseorang melakukan perbuatan pidana korupsi dan hakim tidak dapat memutuskan seseorang bersalah melakukan perbuatan pidana korupsi, 
karena tidak ada kerugian keuangan negara ataupun perekonomian negara yang nyata dan pasti; 10

Dihapuskannya frasa "dapat" juga dapat menjamin kepastian hukum yang adil dalam pemberantasan korupsi sejak dilakukan penyelidikan, penyidikan hingga penuntutan harus sudah ada atau terbukti adanya kerugian keuangan negara atau perekonomian negara yang nyata dan pasti. Hal ini menjadi penting oleh karena salah satu unsur pokok yang harus dibuktikan dalam perkara korupsi adalah unsur "merugikan keuangan negara atau perekonomian negara". Sehingga seseorang dapat menjadi Tersangka, terdakwa atau terpidana melakukan tindak pidana korupsi, karena perbuatannya atau keadaannya berdasarkan bukti sesuai ketentuan undang-undang telah memperkaya diri sendiri atau orang lain atau suatu korporasi, yang dapat merugikan keuangan negara atau perekonomian negara.

Komisi pemberantasan korupsi (KPK) dalam melihat putusan tersebut dianggap sedikit membingungkan, karena terdapat dua putusan, yaitu 003/PUUIV /2006 tahun 2006 dan putusan MK nomor 25/PUU-XIV/2016. KPK menanggap bahwa kedua putusan tersebut sama-sama berlaku, karena pada putusan terakhir tidak menyebutkan menghapuskan putusan sebelumnya, dan menurut KPK pada putusan MK tidak berlaku asas lex posterior derogat legi apriori atau hukum terbaru mengesampingkan hukum yang lama sehingga timbul pertanyaan putusan mana yang harus dijalankan?11

Pada praktiknya, Komisi Pemberantasan Korupsi selalu menggunakan kerugian keuangan negara secara pasti (actual loss) dalam setiap kasus yang mereka tangani. Adapun kesulitan yang dirasakan oleh KPK dengan adanya putusan Mahkamah Konstitusi tersebut ialah tidak bisanya mereka melakukan secara maksimal dalam mengembalikan kerugian negara, karena kerugian negara justru lebih banyak dan akan dirasakan ke depan nanti, seperti halnya kasus suap pada sektor lingkungan hidup.

${ }^{10}$ Wawancara dengan maqdir Ismail, Advokat, Jakarta, 3 Juli 2018

11 Wawancara dengan Efi Laila Kholis, Kabag Litigasi \& Non Litigasi biro Hukum KPK, Jakarta, 16 Juli 
KPK menganalogikan kasus suap yang disertai dengan kerusakan lingkungan hidup ini tidak bisa terlepas dari rantai praktik korupsi korporasi. Praktik korupsi yang selama ini sering terjadi adalah kasus suap antara oknum pemerintah dengan pebisnis, yang mana tujuannya adalah untuk dimudahkan dalam hal perizinan maupun administrasi proyek. Oknum pemerintah tersebut akan menerima sejumlah uang (suap) secara transaksional. Yang kemudian terjadi adalah, operasi tangkap tangan (OTT) KPK seringkali menemui kejadian tersebut. Di mana dalam prosesnya uang OTT yang nyata-nyata ada pada saat operasi tersebut dijadikan barang bukti dan kemudian denda yang dijatuhkan kepada para pelaku hanya sebesar uang suap pada saat OTT.

Jika dilihat pada potential loss, atau kerugian negara yang dapat atau akan ditimbulkan akibat dari kasus di atas adalah lebih banyak dan berat. Bagaimana kemudian nasib lingkungan sekitarnya, kerusakan yang ditimbulkan bukanlah menjadi kajian pokok dalam putusan Mahkamah Konstitusi tersebut. Banyak hutan yang habis dikarenakan praktik korupsi, akan tetapi karena barang bukti hanya lima ratus juta saja, maka mereka hanya bisa dimintai pertanggung jawab lima ratus juta itu juga, sementara dampak atau efek dari korupsi itu tidak menjadi tanggung jawab mereka, sementara negara harus mengurus hutan dan membutuhkan uang serta waktu yang lama, ${ }^{12}$

KPK memahami putusan Mahkamah Konstitusi Nomor 25/PUU-XIV/2016 sebagai salah satu produk hukum yang semakin membatasi upaya atau langkah KPK dalam melakukan kebijakan atau terobosan dalam upaya pemberantasan korupsi. Lebih mendalam, pada kasus kerusakan lingkungan, efek yang ditimbulkan tidak hanya menyebabkan kerugian materiil yang bisa dihitung secara nyata dan pasti, namun kerusakan lingkungan yang efeknya lebih luas, yaitu bagi manusia, serta makhluk hidup lainnya, tidak dapat tersentuh dengan adanya putusan Mahkamah Konstitusi tersebut. Bagaimana tantangan pemberantasan korupsi yang semakin besar, dengan pola yang semakin beraneka ragam, tidaklah bisa dilihat dari satu aspek saja, namun bagaimana negara juga bisa memberikan efek jera kepada para pelaku tindak pidana korupsi.

12 Wawancara dengan Efi Laila Kholis, Kabag Litigasi \& Non Litigasi biro Hukum KPK, Jakarta, 16 Juli 
Praktik Penegakan Hukum yang dilakukan Advokat dan KPK pasca putusan Mahkamah Konstitusi Nomor 25/PUU-XIV/2016

Dalam melihat penegakan Hukum yang dilakukan oleh Advokat pasca putusan MK Nomor 25/PUU-XIV / 2016 tersebut, maka dapat dilihat dari beberapa putusan pengadilan yang ada, yaitu: a. Putusan 30/Pid.Sus-Tpk/2018/PN.Pbr; b. Putusan No. 28/Pid.Sus-TPK/2018/PN.Mdn. c. Putusan No. 191/Pid.Sus.TPK/ 2017/PN-Mdn. d. Putusan No. 191/Pid.Sus.TPK/2017/PN-Mdn.

Di dalam putusan Pengadilan tersebut bahwa penulis melihat Advokat sebagai penasihat Hukum terdakwa tidak melakukan pembelaan berdasarkan putusan MK Nomor 25/PUU-XIV/2016, padahal putusan tersebut sangat membantu terkait mengenai kepastian hukum terdakwa.

Kemudian dalam pertimbangan hukumnya, majelis hakim menekankan tindak pidana korupsi dirumuskan secara tegas sebagai tindak pidana formil yang merupakan hal yang penting dalam pembuktian. Dengan rumusan secara formil yang dimuat dalam undang-undang ini, meskipun hasil korupsi telah dikembalikan kepada negara, pelaku tindak pidana korupsi tetap diajukan ke pengadilan dan tetap dipidana. Selain itu hakim juga menekankan penjelasan Pasal 2 ayat (1) yang menyebutkan bahwa kata "dapat" sebelum frasa "merugikan keuangan atau perekonomian negara" menunjukkan bahwa tindak pidana korupsi merupakan delik formil, yaitu adanya tindak pidana korupsi cukup dengan dipenuhinya unsur-unsur perbuatan yang sudah dirumuskan bukan dengan timbulnya akibat. Dengan demikian dari rumusan tersebut kerugian negara tidaklah mutlak/harus telah terjadi, namun juga dapat dikenakan terhadap kerugian negara yang belum terjadi tetapi perbuatan melawan hukum yang dilakukan tersebut sudah berpotensi akan dapat menimbulkan kerugian negara atau perekonomian negara.

Padahal Mahkamah Konstitusi Republik Indonesia dalam Putusannya tanggal 25 Januari 2017 Nomor 25/PUU-XIV/2016 menyatakan kata "dapat" dalam Pasal 2 ayat (1) dan Pasal 3 Undang-Undang Nomor 31 Tahun 1999 tentang Pemberantasan Tindak Pidana Korupsi sebagaimana diubah dengan UndangUndang Nomor 20 Tahun 2001 tersebut bertentangan dengan Undang-Undang 
Dasar Negara Republik Indonesia Tahun 1945 dan tidak mempunyai kekuatan hukum mengikat. Maka dengan Putusan MK tersebut konsepsi tindak pidana korupsi mengenai kerugian keuangan negara adalah konsepsi kerugian negara dalam arti materil, yakni suatu perbuatan dapat dikatakan merugikan keuangan negara apabila ada kerugian negara yang benar-benar nyata atau aktual.

Namun demikian, tetap ada advokat yang melakukan penegakan hukum dengan menggunakan dasar putusan MK tersebut, misalnya Indra Setiawan adalah Advokat dari Mujono yang diduga korupsi pembangunan kios di atas tanah kas desa Trimulyo justru menuding Inspektorat Daerah Bantul tumpang tindih. Inspektorat tidak memiliki kewenangan menghitung kerugian negara," Merujuk Surat Edaran Mahkamah Agung (SEMA) No. 4/2016 tentang Pemberlakuan Rumusan Hasil Rapat Pleno Kamar MA, Advokat menekankan, hanya Badan Pemeriksa Keuangan (BPK) yang berwenang menyatakan kerugian keuangan negara. Bukan lembaga lain. Terlebih lagi, inspektorat menggunakan metode total loss. Padahal, kerugian negara dalam kasus korupsi harus benar-benar sudah terjadi atau yang sering disebut dengan actual loss. Ini selaras dengan Putusan MK Nomor 25/PUU-XIV /2016. ${ }^{13}$

Jika disimpulkan dari keterangan di atas, Penegakan yang dilakukan oleh advokat dalam Putusan ini mendapat beberapa kendala selain advokat tidak menyinggung putusan MK tersebut walau ada juga yang sudah memakai putusan tersebut sebagai dasar penegakan hukum, sera Majelis Hakim yang masih memakai pertimbangan hukum yang lama sebelum adanya putusan MK. Yaitu Pasal 2 ayat 1 dan Pasal 3 UU Tipikor masih memakai delik formil bukan materil, yang mana hal tersebut mengindikasikan praktik-praktik Penegakan Hukum Tipikor tersebut belum optimal.

Sementara penegakan hukum yang dilakukan KPK Pasca Putusan MK tersebut adalah Pada 2017 KPK melakukan penanganan tindak pidana korupsi dengan rincian: penyelidikan 123 perkara, penyidikan 121 perkara, penuntutan 103 perkara, inkracht 84 perkara, dan eksekusi 83 perkara. Sementara per 31 Mei 2018, di tahun 2018 KPK melakukan penanganan tindak pidana korupsi dengan rincian: penyelidikan 76 perkara, penyidikan 85 perkara, penuntutan 50 perkara, inkracht

13 “Tuding Inspektorat Tak Memiliki Kewenangan" https://www.radarjogja.co.id/2018/06/25/tudinginspektorat-tak-memiliki-kewenangan/ diakses tanggal 4 Oktober 2018. 
47 perkara, dan eksekusi 48 perkara. ${ }^{14}$ Catatan kinerja KPK menunjukkan jumlah penyelidikan dan penyidikan kasus korupsi selama 2017 lebih banyak dibandingkan 2016. Pada 2017-2018 tercatat kasus yang ditangani KPK didominasi oleh perkara suap dan pengadaan barang dan jasa serta tindak pidana pencucian uang. Pelaku korupsi terbanyak berasal dari pejabat birokrasi pemerintahan pusat dan daerah, disusul dari sektor swasta dan DPR/DPRD. ${ }^{15}$

Pasca putusan MK No. 25/PUU-XIV / 2016 terkait penghapusan kata "dapat" pada Pasal 2 ayat (1) dan Pasal 3 UU Tipikor menyebabkan delik pidana menjadi materiil yang berarti unsur kerugian keuangan negara harus terlebih dulu dinyatakan secara nyata (actual loss). Dengan demikian, harus ada penilaian mengenai kerugian keuangan negara yang dilakukan oleh instansi yang berwenang. Sebagai delik materiil, tidak terbuktinya unsur kerugian keuangan negara bisa berakibat bebasnya pelaku korupsi. ${ }^{16}$ Hal ini sedikit banyak menjadikan kekhawatiran bagi KPK dalam upaya pemberantasan korupsi sebagaimana wawancara dengan salah satu internal KPK. Namun, dalam perjalanannya KPK tetap melangkah dengan berbagai upaya-upaya serta terobosan sebagai salah satu komitmennya dalam upaya pemberantasan korupsi di Indonesia.

KPK terus membenahi serta melakukan terobosan dalam upaya pemberantasan tindak pidana korupsi di Indonesia, salah satunya adalah dalam kasus korupsi yang melibatkan Gubernur Sulawesi Utara Nur Alam. Dalam kasus itu, KPK menggunakan dampak kerusakan alam masuk dalam unsur kerugian negara. Dalam perkara ini KPK melakukan terobosan hukum dalam hal metode penghitungan kerugian negara, di mana tidak hanya kerugian materiil dari korupsi, tetapi juga kerugian ekologis, biaya pemulihan lingkungan, dan kerugian ekonomi lingkungan.

Dalam perjalanan kasus tersebut, jaksa kemudian menilai bahwa perbuatan terdakwa Nur Alam telah merugikan keuangan negara Rp 4.300.000.000.000,00.

${ }^{14}$ https://acch.kpk.go.id/id/statistik/tindak-pidana-korupsi diakses pada tanggal 28 Agustus 2018 pukul 16.20 WIB.

15 http://tirto.id/catatan-kinerja-kpk-di-2017-data-kasus-dan-latar-belakang-koruptor-cCn5 diakses pada tanggal 28 Agustus 2018 pukul 16.55 WIB.

16 "KPK Anggap Putusan Delik Tipikor Persulit Pemberantasan Korupsi" http://www.hukumonline.com/berita/baca/lt588989ab4a66c/kpk-anggap-putusan-delik-tipikor-persulitpemberantasan-korupsi diakses tanggal 1 Agustus 2018. 
Angka tersebut tidak sepenuhnya atas hasil penghitungan auditor negara. Sebab, salah satu yang dihitung adalah kerugian akibat kerusakan lingkungan. Jaksa menilai, perbuatan Nur Alam telah mengakibatkan musnahnya atau berkurangnya ekologis/lingkungan pada lokasi tambang nikel di Pulau Kabena yang dikelola PT Anugrah Harisma Barakah sebesar Rp. 2.700.000.000.000,00.

Dari hasil penelitian, terdapat tiga jenis penghitungan kerugian akibat kerusakan lingkungan. Pertama, total kerugian akibat kerusakan ekologis. Kedua, kerugian ekonomi lingkungan. Ketiga, menghitung biaya pemulihan lingkungan. Atas hal tersebut, terdakwa Nur Alam dituntut hukuman 18 tahun penjara oleh jaksa. Dia juga dituntut membayar denda Rp. 1.000.000.000,00 subsider 1 tahun kurungan. Tidak cuma itu, politisi Partai Amanat Nasional itu juga dituntut membayar uang pengganti Rp. 2,700.000.000.000,00 dari keuntungan yang diperoleh dari izin pertambangan yang diberikan Nur Alam kepada pengusaha. Hal ini dinilai penting sebagai terobosan hukum yang akan menjerakan dan memiskinkan pelaku korupsi. "Kerugian negara tersebut harus ditanggung bersama antara Nur Alam dan pihak korporasi yang diuntungkan akibat penerbitan IUP yang dinilai bermasalah. ${ }^{17}$

Vonis ini lebih rendah dari tuntutan jaksa Komisi Pemberantasan Korupsi (KPK) selama 18 tahun. Namun, dalam tuntutan terhadap Nur Alam, pertama kalinya KPK menggunakan kerusakan lingkungan untuk menilai kerugian keuangan negara. Terobosan ini menunjukkan jaksa KPK cukup progresif dalam memperhitungkan kerugian negara akibat korupsi di sektor sumber daya alam, karena menggunakan penghitungan kerugian negara bukan hanya dari kerugian materiil saja tapi dilihat juga kerugian lingkungannya, bahkan sampai biaya pemulihannya.

Nilai kerugian negara yang ditimbulkan dari kasus Nur Alam sangat fantastis, mencapai Rp. 4.300.000.000.000,00. Nilai itu hampir dua kali lipat nilai kerugian negara dalam kasus dugaan korupsi proyek KTP elektronik, yang diklaim mencapai Rp. 2.300.000.000.000,00. Namun, angka tersebut tidak sepenuhnya atas hasil penghitungan auditor negara. Sebab, salah satu yang dihitung adalah

\footnotetext{
17 "ICW Dukung Terobosan KPK Soal Peghitungan Kerugian Negara dari Kerusakan" https://nasional.kompas.com/read/2018/03/28/09052381/icw-dukung-terobosan-kpk-soal-penghitungankerugian-negara-dari-kerusakan diakses tanggal 1 Agustus 2018.
} 
kerugian akibat kerusakan lingkungan. Tidak cuma itu, politikus Partai Amanat Nasional itu juga dituntut membayar uang pengganti Rp. 2.700.000.000,00 dari keuntungan yang diperoleh dari izin pertambangan yang diberikan Nur Alam kepada pengusaha.

\section{Penutup}

Perspektif advokat Pasca putusan MK Nomor 25/PUU-XIV/2016 yaitu perubahan delik formil menjadi delik materiil dianggap lebih memberikan kepastian hukum yang adil sebagaimana dimaksud dalam Pasal 28D ayat (1) UUD 1945, karena unsur kerugian negara haruslah nyata (actual loss) dan dapat dibuktikan terlebih dahulu. Sementara Perspektif KPK terhadap putusan MK Nomor 25/PUU-XIV/2016 terkait penghapusan kata "dapat" pada Pasal 2 ayat (1) dan 3 UU Tipikor dinilai kontraproduktif dalam upaya mencegah kerugian keuangan negara akibat korupsi. Implikasinya adalah KPK semakin sulit untuk menjerat tindak pidana korupsi yang dari sektor sumber daya alam atau lingkungan yang sifatnya berpotensi merugikan keuangan negara (potensial loss). Maka, seharusnya dilakukan pemberitahuan dan atau penyuluhan terhadap putusan MK Nomor 25/PUU-XIV/2016 tentang penghapusan kata dapat dalam Pasal 2 ayat (1) dan Pasal 3 UU Tipikor, agar dalam proses peradilan nantinya advokat mampu secara optimal memperjuangkan hak dari klien-nya yang sejatinya adalah seorang terdakwa kasus korupsi, serta juga hakim dalam memutuskan perkara tidak menggunakan pertimbangan hukum yang lama (delik formil, bukan delik materil).

Praktik penegakan hukum yang dilakukan oleh advokat pasca putusan MK No. 25/PUU-XIV/2016 belum sepenuhnya optimal, karena masih banyak advokat yang tidak menggunakan dasar putusan MK tersebut sebagai dasar pembelaannya walaupun sebagian sudah. Bahkan, hakim dalam pertimbangannya masih menggunakan delik formil dalam melihat UU Tipikor. Sementara praktik penegakan hukum yang dilakukan oleh KPK pasca putusan MK No. 25/PUUXIV/2016 adalah seperti biasanya karena sebelum adanya putusan MK tersebut, KPK selalu mendasarkan kerugian keuangan negara secara pasti, jika pun mereka 
membuat kerugian negara secara potensi, juga melampirkan yang pasti (keduanya). Terkait Potensi tersebut KPK mempunyai maksud dan tujuan mengembalikan kerugian keuangan negara secara optimal, di mana kerugian keuangan negara tidak hanya kerugian materiil dari korupsi, tetapi juga kerugian ekologis, biaya pemulihan lingkungan, dan kerugian ekonomi lingkungan. Perlu adanya aturan secara khusus terkait kerugian ekologis, biaya pemulihan lingkungan, dan kerugian ekonomi lingkungan yang semua itu adalah potensi kerugian keuangan negara (potensial loss). Karena dengan adanya putusan MK tersebut, penegakan hukum terkait yang di atas sangat sulit dilakukan oleh KPK.

\section{Daftar Pustaka}

\section{Buku}

Aminanto, KIF, Politik Hukum Pidana "Disparitas Putusan Hakim dalam Tindak Pidana Korupsi", Kata Media, Jember, 2017.

Danil, Elwi, Korupsi, Konsep, Tindak Pidana dan Pemberntasannya, PT Raja Grafindo Persada, Jakarta, 2011.

Djaja, Ermansjah, Tipologi Tindak Pidana Korupsi di Indonesia, Mandar Maju, Bandung, 2010.

Fadillah, Syarif, Chaerudin, Syaiful Ahmad Dinar, Strategi Pencegahan dan Penegakan Hukum Tindak Pidana Korupsi, PT Refika Aditama, Jakarta, 2009.

Prasetyo, Teguh, Hukum Pidana Materiil, Kurnia Kalam, Yogyakarta, 2005.

Rahardjo, Satjipto, "Penegakan Hukum Progresif", Kompas, Jakarta, 2010.

\section{Internet}

http:/ / www.antikorupsi.org/sites/antikorupsi.org/files/doc/Kajian/policypap erkeuangannegara.pdf.

http:/ / www.hukumonline.com/berita/baca/lt588989ab4a66c/kpk-anggapputusan-delik-tipikor-persulit-pemberantasan-korupsi

https:/ / acch.kpk.go.id/id/statistik/tindak-pidana-korupsi

https:/ / nasional.kompas.com/read/2018/03/28/09052381/icw-dukungterobosan-kpk-soal-penghitungan-kerugian-negara-dari-kerusakan

https://www.bbc.com/indonesia/indonesia-43554605

https://nasional.kompas.com/read/2017/03/14/07100021/kasus.bupati.nonakti f.sabu.raijua.kpk.lakukan.pelimpahan.tahap.dua

https: / / www.radarjogja.co.id/2018/06/25/tuding-inspektorat-tak-memilikikewenangan/ 